Brit. J. industr. Med. 1947, 4, 216.

\title{
THE RISK OF FLUOROSIS IN MAGNESIUM FOUNDRIES
}

BY

\author{
R. G. BOWLER, MONAMY BUCKELL, JESSIE GARRAD, A. BRADFORD HILL, \\ DONALD HUNTER, KENNETH M. A. PERRY, and R. S. F. SCHILLING \\ From the Department for Research in Industrial Medicine (Medical Research Council), \\ The London Hospital
}

(RECEIVED FOR PUBLICATION, JUNE 9, 1947)

\section{Introduction}

Magnesium alloys were first used in foundries in about 1935, but since then, and particularly with the expansion of the aircraft industry during the war 1939-45, their use has been extensive. According to Ford and Stern (1944), 530,000,000 pounds were used in the United States in 1944 in contrast to $6,000,000$ pounds in 1939 . The greatest risk in magnesium foundries is fire. Serious fires occurred in Germany in 1939 ; in Little Falls, New Jersey, in June, 1939 ; at Hounslow, England, in February, 1940 ; in Cleveland, Ohio, in December, 1940 ; and in New York in January, 1944. The alloys are safe except when the metal is molten or in finely divided form. When the metal is melted it rapidly oxidizes and ignites unless (a) air is excluded from the surface by a flux which usually contains fluoride, or (b) air is replaced by a reducing gas such as sulphur dioxide. Special oxidation inhibitors such as boric acid, sulphur, borax, or soluble fluorides, when added to moulding sands make it possible to pour molten magnesium into damp sand moulds without the danger of fire or explosion. It is evident, however, that if fluorides are used as a flux for the metal, and in the moulding and core sands, workers in such foundries might be exposed to a risk of fluorosis from atmospheric contamination.

\section{Previous Investigation}

To investigate this risk Largent and Ferneau (1944) collected spot samples of urine from men engaged in magnesium founding and analysed them for fluorine. They showed by controlled experiments that the fluorine concentrations in spot urine samples differed somewhat from the concentration in a twenty-four-hour urine sample from the same individual but the mean concentration for an entire group of spot samples did not differ significantly from that of a group of twenty-four-hour samples.
This work was carried out in three foundries, and the results are shown in Table 1.

TABLE 1

MEAN FLUORINE CONCENTRATIONS IN P.P.M. IN SPOT SAMPLES OF URINE COLLECTED FROM THREE MAGNESIUM FOUNDRIES (from Largent and Ferneau 1944)

\begin{tabular}{c|c|c|c|c}
\hline Foundry & $\begin{array}{c}\text { No. of } \\
\text { Samples }\end{array}$ & $\begin{array}{c}\text { Mean and its } \\
\text { P.E.* }\end{array}$ & S.D. $\dagger$ & C. of.V.t \\
\hline A & 123 & $2 \cdot 23 \pm 0.087$ & 1.4317 & $64 \cdot 16$ \\
B & 12 & $3.13 \pm 0.381$ & 1.9592 & 62.70 \\
C & 6 & 6.39 & 5.5695 & 86.87 \\
\hline
\end{tabular}

* Probable error of the mean; $\dagger$ standard deviation; $\ddagger$ coefficient

In foundry $A$ the numbers were sufficiently large to analyse the results according to the part of the foundry in which the men were working. The results are given in Table 2.

Table 2

MEAN FLUORINE CONCENTRATIONS IN P.P.M. IN URINE SAMPLES OBTAINED FROM WORKMEN IN FOUNDRY A ; GROUPED ACCORDING TO PLACE OF WORK IN FOUNDRY (from Largent and Ferneau, 1944)

\begin{tabular}{lc|c|c|c}
\hline \multicolumn{1}{c|}{ Place of Work } & $\begin{array}{c}\text { Mean and } \\
\text { its P.E. }\end{array}$ & S.D. & C. of V. \\
\hline Core Spray &. & $3.45 \pm 0.388$ & 2.821 & 81.56 \\
Pouring . . &. & $2.13 \pm 0.157$ & 1.250 & 58.71 \\
Knock-out &. & $1.97 \pm 0.105$ & 1.031 & 52.44 \\
Melting .. &.. & $1.56 \pm 0.118$ & 1.175 & 75.28 \\
Core room &.. & $1.50 \pm 0.087$ & 0.997 & 66.45 \\
Fettling .. &.. & $1.37 \pm 0.142$ & 1.015 & 74.26 \\
\hline
\end{tabular}

Two air samples from foundry B, both collected in the knock-out area, showed fluorine concentrations of $31 \mathrm{mg}$. and $84 \mathrm{mg}$. per 10 cubic metres. 
The concentration was $60 \mathrm{mg}$. per 10 cubic metres in one air sample collected in foundry $A$ in the coresetting area between the pouring and knock-out areas. It was assumed that each worker breathed 10 cubic metres of air per day. The authors considered there was evidence that workers in these occupations were exposed to a risk of developing fluorosis. In view of these results it was decided to investigate conditions in a magnesium foundry in England.

\section{Present Investigation}

The foundry investigated, in a country town in Southern England, was producing castings of magnesium-aluminium-zinc, magnesium-aluminiummanganese, and magnesium-aluminium- manganesesilver alloys. The following processes were carried out : the metal was melted in open crucibles or in an almost enclosed bale-out type of furnace ; the flux used in every case contained a considerable amount of fluoride (about 15 per cent.); before pouring, the crust which formed on the melt was removed and a fluoride-containing dusting powder was sprinkled on top of the molten metal. Aluminium fluoride, to the extent of about 2 per cent. of the final mix, was added, either as solid or solution, to the sand used for moulding. Thus, possible sources of danger from fluoride were as follows : (1) in adding the flux to the open crucibles ; (2) in the application of dusting powder to the molten metal ; (3) in sand preparation; (4) in casting and in the process of knocking out.

The moulds were filled with sulphur dioxide from a cylinder immediately before pouring, a considerable amount being given off into the atmosphere, particularly during pouring. The high concentration of sulphur dioxide in the air was partly due to the fact that the dusting powder contained 60 per cent. sulphur.

TABLE 3

MASS CONCENTRATION AND FLUORINE CONTENT OF AIRBORNE DUST SAMPLES TAKEN AT VARIOUS POINTS IN THE FACTORY

\begin{tabular}{|c|c|c|c|c|}
\hline Sampling point & & $\begin{array}{c}\text { Vol. of } \\
\text { sample } \\
\left(\mathrm{m}^{3}\right)\end{array}$ & $\underset{\mathrm{Mg} . / \mathrm{m}^{3}}{\text { Dust }}$ & $\begin{array}{l}\text { Fluorine } \\
\mathrm{Mg} . / \mathrm{m}^{3}\end{array}$ \\
\hline $\begin{array}{l}\text { Core shop.. } \\
\text { Foundry proper : }\end{array}$ & $\cdots$ & $10 \cdot 2$ & $3 \cdot 3$ & $0 \cdot 143$ \\
\hline $\begin{array}{l}\text { Mixing mill } \\
\text { Machine mould } \\
\text { Near mechanical feed } \\
\text { Near furnaces } 1 . .\end{array}$ & $\begin{array}{l}\cdots \\
\cdots \\
\cdots\end{array}$ & \begin{tabular}{|l|}
$10 \cdot 2$ \\
$10 \cdot 2$ \\
$10 \cdot 2$ \\
$10 \cdot 2$
\end{tabular} & $\begin{array}{r}12 \cdot 5 \\
3 \cdot 5 \\
8 \cdot 3 \\
4 \cdot 3\end{array}$ & $\begin{array}{l}6 \cdot 370 \\
0 \cdot 286 \\
0 \cdot 714 \\
0 \cdot 314\end{array}$ \\
\hline$" \quad, \quad 2 \ldots$ & $\cdots$ & $\begin{array}{c}\text { Not } \\
\text { recorded }\end{array}$ & - & $\begin{array}{l}\text { Fluorine } \\
\text { in dust } \\
7 \cdot 5 \%\end{array}$ \\
\hline
\end{tabular}

Fluorine Content of Dust Samples.-Dust samples were collected on a salicylic acid filter. The volume of air sampled was recorded and the mass concentration of dust at the various sampling points calculated from the weight of dust obtained after dissolving out the salicylic acid in ethyl alcohol. The alcohol washings were retained and analysed for fluorine and this figure was combined with that for the fluorine found in the dust. The determination of fluorine was carried out using a modification of the method of Willard and Winter (1933). No attempt was made to trap gaseous fluorine, but it is possible that some of this might have been retained by the salicylic acid filter bed.

Thermal precipitator samples were taken near the open crucibles; the slides showed a cloud of fine, white, very hygroscopic particles, presumably from flux or dusting powder.

Population of Workmen Examined.-About 190 were employed in the foundry and core shop, and 124 of these volunteered to be examined. It - was not possible to examine all the workers, or even a randomly selected cross-section of them, owing to (a) staggered holidays, (b) the progressive reduction in personnel on the grounds of redundancy while the investigation was in progress, and $(c)$ the reluctance of some men to participate. The volunteers included, however, workers in the different occupations, with varying durations of exposure and of varying ages, as is shown in Tables 4 and 5 . On the other hand, as stated below, only some of these men submitted to a complete examination, with radiograph and with blood and urine tests. While it is impossible to maintain with certainty that these varying samples of the men are representative of all those involved, it is believed that they are sufficient to supply some of the necessary data and give at least a broad indication of the possible risks of fluorosis in this environment.

Nature of Examination.-The examination included occupational and clinical histories, physical examination, chest expansion measurements, and vital capacity.

On the first two days of the enquiry a sample of $10 \mathrm{ml}$. of venous blood was collected from alternate men examined, but when it became evident that the total

\section{TABLE 4}

DISTRIBUTION OF WORKERS EXAMINED BY AGE AND OCCUPATION

\begin{tabular}{|c|c|c|c|c|c|}
\hline Occupation & No. & \multicolumn{4}{|c|}{ Age in years } \\
\hline \multirow{8}{*}{$\begin{array}{l}\text { Moulders } \\
\text { Machine moulders } \\
\text { Furnacemen } \\
\text { Crane drivers } \\
\text { Labourers } \\
\begin{array}{l}\text { Core makers } \\
\text { Core oven atten- } \\
\text { dants .. }\end{array}\end{array}$} & & $15-29$ & $30-39$ & $40-49$ & $50-59$ \\
\hline & 45 & 10 & 24 & 9 & 2 \\
\hline & 8 & 3 & 4 & 1 & - \\
\hline & 16 & 3 & 8 & 4 & 1 \\
\hline & 3 & - & 2 & 1 & - \\
\hline & 23 & 6 & 1.1 & 3 & 3 \\
\hline & 26 & 10 & 10 & 4 & 2 \\
\hline & 3 & & 1 & 1 & 1 \\
\hline & & & & & \\
\hline Total & 124 & 32. & 60 & 23 & 9 \\
\hline
\end{tabular}


TABLE 5

DISTRIBUTION OF WORKERS EXAMINED BY YEARS OF WORK IN MAGNESIUM FOUNDRIES

\begin{tabular}{|c|c|c|c|c|}
\hline Occupation & No. & \multicolumn{3}{|c|}{ Years of work } \\
\hline & & Under 2 & $2-5$ & $\begin{array}{l}6 \text { and } \\
\text { over }\end{array}$ \\
\hline $\begin{array}{ll}\text { Moulders } & \text {.. } \\
\text { Machine moulders } & \ldots \\
\text { Furnacemen } & \ldots \\
\text { Crane drivers } & \ldots \\
\text { Labourers .. } & \ldots \\
\text { Core makers.. } & \ldots \\
\text { Core oven attendants }\end{array}$ & $\begin{array}{r}.45 \\
8 \\
16 \\
3 \\
23 \\
26 \\
3\end{array}$ & $\begin{array}{l}14 \\
1 \\
2 \\
8 \\
2 \\
2\end{array}$ & $\begin{array}{r}13 \\
4 \\
7 \\
14 \\
9 \\
1\end{array}$ & $\begin{array}{r}18 \\
4 \\
8 \\
1 \\
1 \\
15 \\
-\end{array}$ \\
\hline Total & 124 & 29 & 48 & 47 \\
\hline
\end{tabular}

number of volunteers would be smaller than anticipated a sample was collected from every man on the two subsequent days. From this a full blood count was taken and the rest was stored for fluorine determination. Of the 80 samples of blood thus obtained, 17 were taken into waxed tubes in order to prevent absorption of fluorine by the glass, but the remaining 63 were in unwaxed tubes. The results were expressed as parts per million whole blood. Although the mean figure for the waxed tubes was higher than that for the unwaxed the difference is not large and not more than might easily be due to chance (Table 6). In subsequent analysis the two sets of figures have, therefore, been combined.

TABLE 6

\begin{tabular}{|c|c|c|}
\hline Method of storage & No. & $\begin{array}{c}\text { Mean } \\
\text { F.p.p.m. }\end{array}$ \\
\hline $\begin{array}{lll}\text { Unwaxed tubes } & \ldots & \ldots \\
\text { Waxed tubes } & \ldots & \ldots \\
\text { Difference } & & \therefore \\
\quad \text { Statistical } & \text { significance- }\end{array}$ & $\begin{array}{c}63 \\
17 \\
\text { "t } t-0.9021 . P\end{array}$ & $\begin{array}{c}2 \cdot 48 \\
2 \cdot 84 \\
0.36 \\
=\cdot 3 \text { to } \cdot 4\end{array}$ \\
\hline
\end{tabular}

The men were asked to co-operate by collecting twenty-four hour specimens of urine at the week-end in order to avoid contamination in the foundry, but only nine were willing to do this. It was decided, therefore, to obtain as many spot samples as possible; these were given by 57 workers. To avoid contamination these specimens were passed in the ambulance room under medical supervision, and were collected in waxed bottles. The fluorine content of these samples was expressed as parts per million and the specific gravity of each specimen was recorded.

Radiographs were taken of the chest, jaw, spine, pelvis, and radius and ulna. The chest radiographs were taken with a different mobile $x$-ray apparatus from that used for the bone radiographs ; they were, therefore, not done on the same day, and accordingly the numbers do not correspond exactly, since some of the men did not attend on both occasions.

\section{Findings}

Incidence of Reticulation.-Radiographs of the workers' chests showed evidence of reticulation. This was of the type found in foundries in general; it has been the subject of another investigation, which will be published later. The exact incidence, arranged according to the age of the workers and the length of exposure in foundries, is recorded in Tables 7 and 8 . Seventy-eight of the men had their chests radiographed.

TABLE 7

\section{INCIDENCE OF RETICULATION BY} AGE AND OCCUPATION

\begin{tabular}{|c|c|c|c|c|c|}
\hline \multirow{2}{*}{ Occupation } & \multirow{2}{*}{ Total } & \multicolumn{4}{|c|}{ Age in years } \\
\hline & & $15-29$ & $30-39$ & $40-49$ & $50-59$ \\
\hline $\begin{array}{l}\text { Moulders .. } \\
\text { Machine } \\
\quad \text { moulders } \\
\text { Furnacemen } \\
\text { Crane drivers } \\
\text { Labourers .. } \\
\text { Core makers } \\
\text { Core oven } \\
\text { attendants }\end{array}$ & $\begin{array}{cc}13 & (28) \\
1 & (3) \\
3 & (11) \\
- & (2) \\
5 & (16) \\
5 & (15) \\
1 & (3)\end{array}$ & $\begin{array}{r}3(7) \\
1 \quad(1) \\
-\quad(2) \\
1 \quad(5) \\
-\quad(4) \\
-\quad(1)\end{array}$ & $\begin{array}{rr}6 & (15) \\
- & (2) \\
1 & (6) \\
- & (2) \\
1 & (6) \\
3 & (6) \\
- & (1)\end{array}$ & $\begin{array}{l}2(4) \\
1- \\
1-(2) \\
1-(3) \\
1 \quad(3) \\
-\end{array}$ & $\begin{array}{l}2(2) \\
1 \overline{(1)} \\
2 \frac{(2)}{1(2)} \\
1(1)\end{array}$ \\
\hline Total & $28(78)$ & $5(20)$ & $11(38)$ & $5(12)$ & $7(8)$ \\
\hline
\end{tabular}

(Figures in brackets show the total number radiographed)

TABLE 8

INCIDENCE OF RETICULATION BY YEARS OF WORK IN MAGNESIUM FOUNDRIES

\begin{tabular}{|c|c|c|c|c|}
\hline \multirow{2}{*}{ Occupation } & \multirow{2}{*}{ Total } & \multicolumn{3}{|c|}{ Years of work } \\
\hline & & Under 2 & $2-6$ & Over 6 \\
\hline $\begin{array}{ll}\text { Moulders } & . . \\
\text { Machine moulders } & \ldots \\
\text { Furnacemen... } & \ldots \\
\text { Crane drivers } & \ldots \\
\text { Labourers .. } & \ldots \\
\text { Core makers.. } & \ldots \\
\text { Core oven attendants }\end{array}$ & \begin{tabular}{|rr}
13 & $(28)$ \\
1 & $(3)$ \\
3 & $(11)$ \\
$-\quad(2)$ \\
5 & $(16)$ \\
5 & $(15)$ \\
1 & $(3)$
\end{tabular} & $\begin{array}{r}3(9) \\
-\quad(1) \\
-\quad(2) \\
-\quad(8) \\
-\quad(1) \\
1 \quad(1)\end{array}$ & $\begin{array}{rr}5 & (13) \\
1 & (2) \\
2 & (5) \\
5- \\
5 & (5) \\
2 & (5) \\
- & (1)\end{array}$ & $\begin{array}{r}5 \quad(6) \\
-1(1) \\
1 \quad(5) \\
-\quad(3) \\
3 \quad(9) \\
-\quad(1)\end{array}$ \\
\hline Total & $28(78)$ & $4(22)$ & $15(31)$ & $9(25)$ \\
\hline
\end{tabular}

Vital Capacities. - The vital capacities of the workers (Táble 9) showed no significant difference between the groups, except that the latest recruits to the foundry had a rather low vital capacity. The reason for this is not evident, but.it might be due to the low standard of physical fitnéss in those rejected for military service and thus left available for work in industry. Since the radiographs were taken before the clinical examinations were made, the numbers are not identical for the two investigations. Some men were unwilling to attend at the second visit, while some had been 
discharged on grounds of redundancy since the factory was closing.

Fluorine.-The fluorine content of blood and urine samples was determined by a modification of the method of Willard and Winter (1933); the results are given in Table 10.

The nine subjects who gave twenty-four hour specimens of urine were found to be excreting from 0.35 (0.4 p.p.m.) to 3.80 (2.8 p.p.m.) with a mean of $1 \cdot 10 \mathrm{mg}$. fluorine every twenty-four hours $(1.3$ p.p.m.). A summary of the excretion of fluorine in the 53 spot samples, grouped according to years of exposure, is given in Table 13. The specific gravities of these samples were in the range of 1.005 to 1.037 , with a mean of 1.027 . These results show, by comparison with the control series, that there is a slightly increased excretion of fluorine in all the groups of workers except those who had been at the foundry for less than two years.

In the groups labelled "core shop" and " furnacemen" there' was no significant difference between those who had been exposed for more than 6 years and those with shorter exposure. The difference between the three exposure groups amongst the foundry workers is more than is likely to be due to chance, and shows a progressive increase in fluorine excretion with longer exposure. The mean value for the urinary fluorine excretion of all the workers examined in this magnesium foundry is 2.50 p.p.m., which is very close to the mean value of 2.48 observed by Largent and Ferneau for 141 subjects (Table 1).

It is unlikely that the increased excretion of fluorine was due to a high intake in the drinking water, because the fluorine content of the water supply in the district in which the foundry was situated, and of that in which the workers lived, was 0.15 and 0.18 p.p.m. respectively, whilst the water supply used by the control group from a town in England, some miles distant from the foundry, contained 0.09 p.p.m., and the two supplies available to the other control group in Scotland contained 0.07 and 0.18 p.p.m.

On the other hand the blood fluorine level in the different groups of workers at the foundry (Table 11) showed no significant difference with duration of exposure. These figures, giving a mean of 2.58 p.p.m. can be compared with a group of residents in Scotland, and reveal no significant difference.

Blood Counts.-The results of the hæmatological examination are given in Table 12. The hæmoglobin was estimated by the photoelectric alkaline hæmatin method. $(13.8 \mathrm{mg}$. per $100 \mathrm{~g} .=100$ per cent.) These results show no abnormalities.

Radiographic Changes.-Radiographic changes rarely become manifest until the worker has been exposed to excessive quantities of fluorine for more than seven years (M.R.C. Report on fluorosis in Fort William-to be published). Since magnesium founding has only been performed for some ten years, and only extensively for about five years, the number of men exposed for a sufficient length of time to show these changes must necessarily be few. Only one man in this foundry showed radiographic changes in his bones suggestive of fluorosis. No changes which could be considered significant were seen in other men who had their bones radiographed.

\section{Case Report}

A man aged 37 had seen service in the army and four years in agricultural work before coming to the magnesium foundry to work as a furnaceman on the open crucible furnaces, which he had done for the past five and a half years. He had no symptoms and no abnormal physical signs. He had had three teeth extracted; two were carious and six were filled. His blood count showed 5,500,000 red cells, and 11,000 white cells, of which 61 per cent. were polymorphs, 34 per cent. lymphocytes, 2 per cent. monocytes, 2 per cent. eosinophils, and 1 per cent. basophils. The hæmoglobin

TABLE 9

VITAL CAPACITIES IN ML.

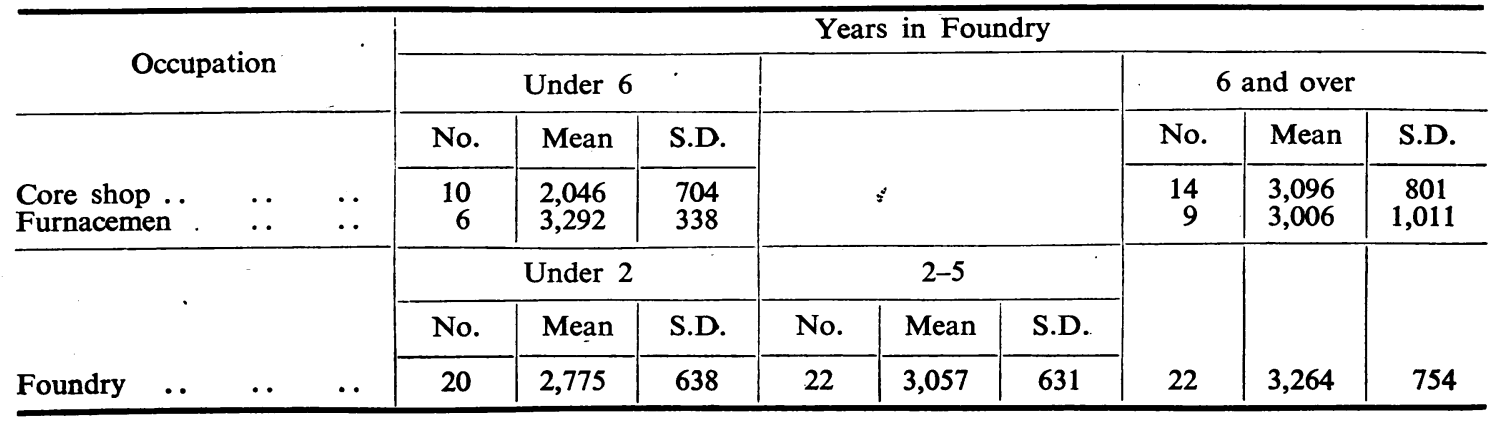


TABLE 10

FLUORINE CONTENT OF BLOOD AND URINE SAMPLES

\begin{tabular}{|c|c|c|c|c|c|c|c|c|c|c|c|}
\hline \multirow{4}{*}{ No. } & \multirow{4}{*}{ Age } & \multicolumn{3}{|c|}{ Fluorine Content p.p.m. } & \multirow{4}{*}{$\begin{array}{l}\text { Urine } \\
\text { 24-hr. } \\
\text { samples } \\
\text { mg. } \\
\text { F. per } \\
24 \text { hrs. }\end{array}$} & \multirow{4}{*}{ No. } & \multirow{4}{*}{ Age } & \multicolumn{3}{|c|}{ Fluorine Content p.p.m. } & \multirow{4}{*}{$\begin{array}{c}\text { Urine } \\
\text { 24hr. } \\
\text { samples } \\
\text { mg. } \\
\text { F. per } \\
24 \text { hrs. }\end{array}$} \\
\hline & & \multirow{3}{*}{ Blood } & \multirow{2}{*}{\multicolumn{2}{|c|}{$\frac{\text { Urine }}{\text { Spot Samples }}$}} & & & & \multirow{3}{*}{ Blood } & \multirow{2}{*}{\multicolumn{2}{|c|}{$\frac{\text { Urine }}{\text { Spot Samples }}$}} & \\
\hline & & & & & & & & & & & \\
\hline & & & F.p.p.m. & Sp. Gr. & & & & & F.p.p.m. & Sp. Gr. & \\
\hline \multirow{26}{*}{$\begin{array}{r}1 \\
2 \\
3 \\
4 \\
5 \\
6 \\
7 \\
8 \\
9 \\
10 \\
11 \\
12 \\
13 \\
14 \\
15 \\
16 \\
17 \\
18 \\
19 \\
20 \\
21 \\
22 \\
23 \\
24 \\
25\end{array}$} & \multirow{26}{*}{$\begin{array}{l}48 \\
39 \\
55 \\
26 \\
23 \\
23 \\
21 \\
41 \\
34 \\
37 \\
32 \\
34 \\
44 \\
25 \\
22 \\
36 \\
30 \\
36 \\
47 \\
24 \\
20 \\
54 \\
53 \\
39 \\
24\end{array}$} & \multirow{3}{*}{$\overline{1 \cdot 4}$} & Core Shop & \multirow[b]{2}{*}{1.024} & & 49 & 33 & - & $1 \cdot 0$ & $1 \cdot 016$ & - \\
\hline & & & 3.8 & & - & 50 & 30 & $2 \cdot 4$ & $1 \cdot 4$ & 1.028 & - \\
\hline & & & 3.5 & 1.031 & - & 51 & 42 & $1 \cdot 5$ & - & - & 二 \\
\hline & & & & 1.037 & 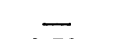 & 52 & 41 & 1.8 & - & - & - \\
\hline & & 0.8 & & 1.025 & 0.78 & 53 & 45 & $2 \cdot 4$ & - & - & 一 \\
\hline & & $4 \cdot 2$ & 0.9 & 1.031 & - & 54 & 42 & 2.5 & $\overline{2.7}$ & $\overline{000}$ & - \\
\hline & & 1.5 & $3 \cdot 3$ & 1.031 & - & 55 & $35^{\circ}$ & 2.5 & 3.7 & $1 \cdot 029$ & - \\
\hline & & $\begin{array}{l}2 \cdot 0 \\
3.0\end{array}$ & 二 & 二 & 二 & 56 & $\begin{array}{l}37 \\
30\end{array}$ & $\begin{array}{l}2 \cdot 1 \\
1 \cdot 5\end{array}$ & $\overline{2 \cdot 3}$ & $1 \cdot \overline{026}$ & - \\
\hline & & $\begin{array}{l}3.0 \\
4.7\end{array}$ & 二 & 二 & 二 & 58 & $\begin{array}{l}30 \\
29\end{array}$ & $2 \cdot 9$ & - & - & - \\
\hline & & 1.6 & $3 \cdot 0$ & 1.026 & - & 59 & 37 & $1 \cdot 5$ & $\overline{-1}$ & $\overline{0}$ & - \\
\hline & & $4 \cdot 7$ & 0.9 & - & - & 60 & 45 & 1.9 & $5 \cdot 3$ & 1.027 & 一 \\
\hline & & $2 \cdot 6$ & $1 \cdot 6$ & 1.028 & - & 61 & 33 & $1 \cdot 7$ & - & & - \\
\hline & & & $2 \cdot 8$ & 1.029 & - & 62 & 32 & - & 2.6 & 1.024 & - \\
\hline & & $4 \cdot 3$ & $4 \cdot 0$ & 1.024 & - & 63 & 26 & - & 0.9 & 1.029 & - \\
\hline & & $4 \cdot 2$ & $1 \cdot 4$ & 1.029 & - & 64 & 22 & $8 \cdot 4$ & 5 & $\overline{020}$ & - \\
\hline & & $1 \cdot 2$ & - & - & - & 65 & 52 & - & $3 \cdot 8$ & 1.036 & - \\
\hline & & $1 \cdot 1$ & - & - & - & 66 & 31 & $2 \cdot 6$ & - & - & - \\
\hline & & $2 \cdot 0$ & 1.9 & $1 \cdot 022$ & - & 67 & 37 & $4 \cdot 5$ & $-\overline{1}$ & $\ldots$ & - \\
\hline & & 3.9 & -1 & $\overline{002}$ & - & 68 & 42 & $4 \cdot 2$ & $5 \cdot 1$ & 1.026 & - \\
\hline & & $1 \cdot 3$ & $4 \cdot 1$ & 1.036 & - & 69 & 34 & $6 \cdot 1$ & $7 \cdot 5$ & 1.028 & - \\
\hline & & $1 \cdot 5$ & $2 \cdot 9$ & - & 一 & 70 & 34 & $3 \cdot 1$ & $1 \cdot 5$ & 1.025 & - \\
\hline & & $2 \cdot 3$ & -8 & - & - & 71 & 31 & 1.5 & - & - & - \\
\hline & & $2 \cdot 3$ & 1.9 & - & - & 72 & 32 & 2.6 & $2 \cdot 0$ & 1.035 & - \\
\hline & & $2 \cdot$ & - & $\div$ & $0 \cdot 35$ & 73 & 37 & $1 \cdot 5$ & - & - & 一 \\
\hline & & $5 \cdot$ & $1 \cdot 7$ & 1.020 & $3 \cdot 8$ & 74 & 46 & $1 \cdot 7$ & - & $\overline{0}$ & - \\
\hline & & & Foundry & & & 76 & 30 & $0 \cdot 9$ & $1 \cdot 2$ & 1.030 & 二 \\
\hline 26 & 29 & 3.9 & $2 \cdot 7$ & 1.031 & - & 77 & 22 & - & $2 \cdot 5$ & 1.030 & - \\
\hline 27 & 31 & $2 \cdot 6$ & $\sigma$ & - & - & 78 & 22 & 2.9 & - & - & - \\
\hline 28 & 25 & 1.9 & $\overline{2 \cdot 7}$ & $1 \cdot \overline{026}$ & - & 79 & 22 & $1 \cdot 9$ & $\overline{1.8}$ & $1 . \overline{036}$ & 二 \\
\hline $\begin{array}{l}29 \\
30\end{array}$ & $\begin{array}{l}42 \\
38\end{array}$ & $\overline{2 \cdot 9}$ & $\begin{array}{l}2 \cdot 7 \\
3.7\end{array}$ & $\begin{array}{l}1.026 \\
1.026\end{array}$ & - & $\begin{array}{l}80 \\
81\end{array}$ & $\begin{array}{l}28 \\
36\end{array}$ & - & $1 \cdot 8$ & 1.036 & $0 . \overline{74}$ \\
\hline 31 & 33 & 1.6 & $2 \cdot 6$ & 1.024 & - & 82 & 38 & 1.6 & - & - & 0.78 \\
\hline 32 & 31 & $1 \cdot 1$ & 0.5 & 1.031 & - & 83 & 31 & 1.8 & $1 \cdot 4$ & - & $1 \cdot 10$ \\
\hline 33 & 33 & 2.0 & $2 \cdot 6$ & 1.028 & - & & & & Furnace- & & \\
\hline 34 & 33 & $1 \cdot 0$ & & & - & & & & men & & \\
\hline 35 & 22 & $2 \cdot 6$ & $3 \cdot 0$ & 1.032 & - & 84 & 45 & 3.6 & $2 \cdot 2$ & $1 \cdot 027$ & - \\
\hline 36 & 29 & $2 \cdot 6$ & 1.0 & 1.027 & - & 85 & 0 & 0.6 & - & - & - \\
\hline 37 & 23 & $2 \cdot 3$ & & & - & 86 & 32 & $2 \cdot 1$ & $\overline{1.5}$ & $\overline{1.032}$ & - \\
\hline 38 & 25 & - & $4 \cdot 5$ & 1.037 & - & 87 & 30 & $1 \cdot 4$ & $1 \cdot 5$ & 1.033 & 一 \\
\hline 39 & 39 & - & $1 \cdot 1$ & 1.029 & - & 88 & 36 & $=$ & $2 \cdot 7$ & 1.024 & - \\
\hline 40 & 38 & 1.9 & 6.9 & 1.029 & - & 89 & 29 & 1.7 & - & - & - \\
\hline 41 & 35 & 1.4 & $1 \cdot 0$ & 1.026 & - & 90. & 36 & $2 \cdot 3$ & - & - & - \\
\hline 42 & 49 & $2 \cdot 0$ & & & - & 91 & 46 & $5 \cdot 0$ & - & - & - \\
\hline 43 & 40 & $2 \cdot 3$ & $1 \cdot 8$ & 1.028 & - & 92 & 50 & $4 \cdot 7$ & - & - & - \\
\hline 44 & 57 & $1 \cdot 2$ & - & - & - & 93 & 30 & $3 \cdot 5$ & - & - & - \\
\hline 45 & 34 & $7 \cdot 1$ & - & - & - & 94 & 37 & $4 \cdot 6$ & - & - & - \\
\hline 46 & 31 & - & $1 \cdot 6$ & 1.026 & ' & 95 & 32 & $1 \cdot 0$ & $1 \cdot 0$ & 1.005 & 0.98 \\
\hline$A^{2}$ & 34 & $1 \cdot 5$ & $\pi$ & & - & 9 & 33 & 1.6 & $2 \cdot 6$ & 1.017 & 0.39 \\
\hline 48 & 38 & - & $2 \cdot 3$ & 1.023 & - & 97 & 46 & 2.5 & 3.4 & 1.021 & $1 \cdot 10$ \\
\hline
\end{tabular}


TABLE 11

BLOOD FLUORINE IN P.P.M. BY LENGTH AND TYPE OF EXPOSURE

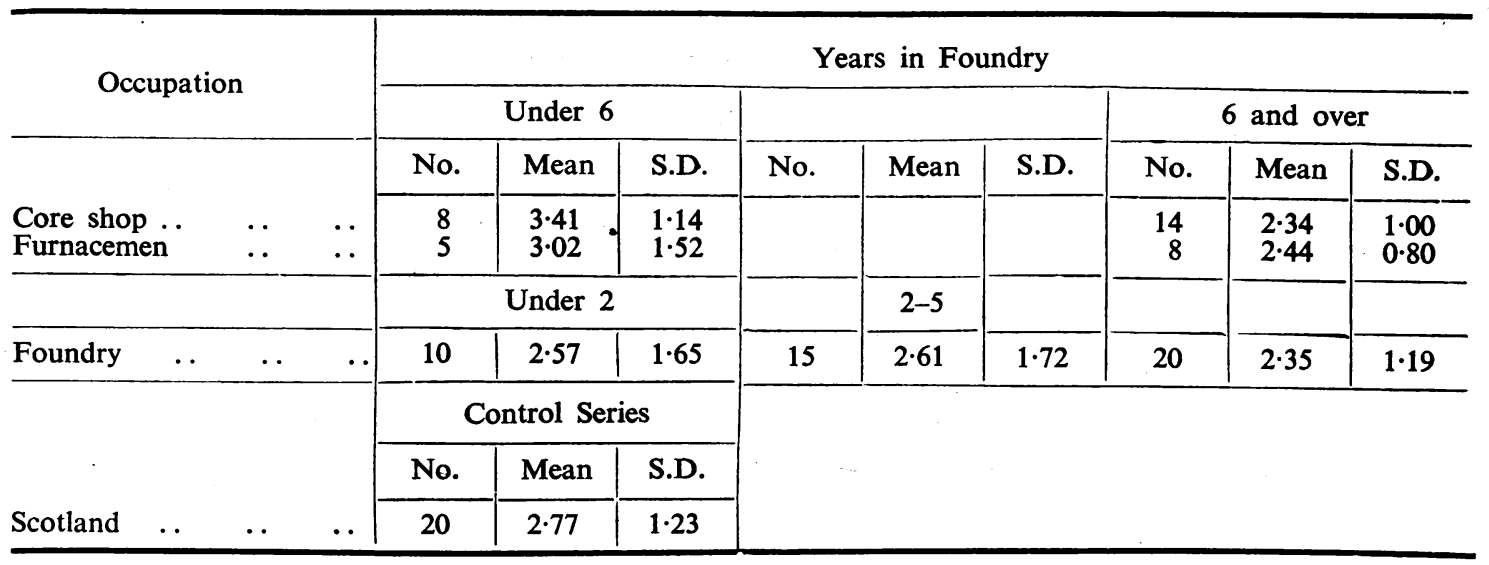

TABLe 12

DETAILS OF BLOOD COUNTS

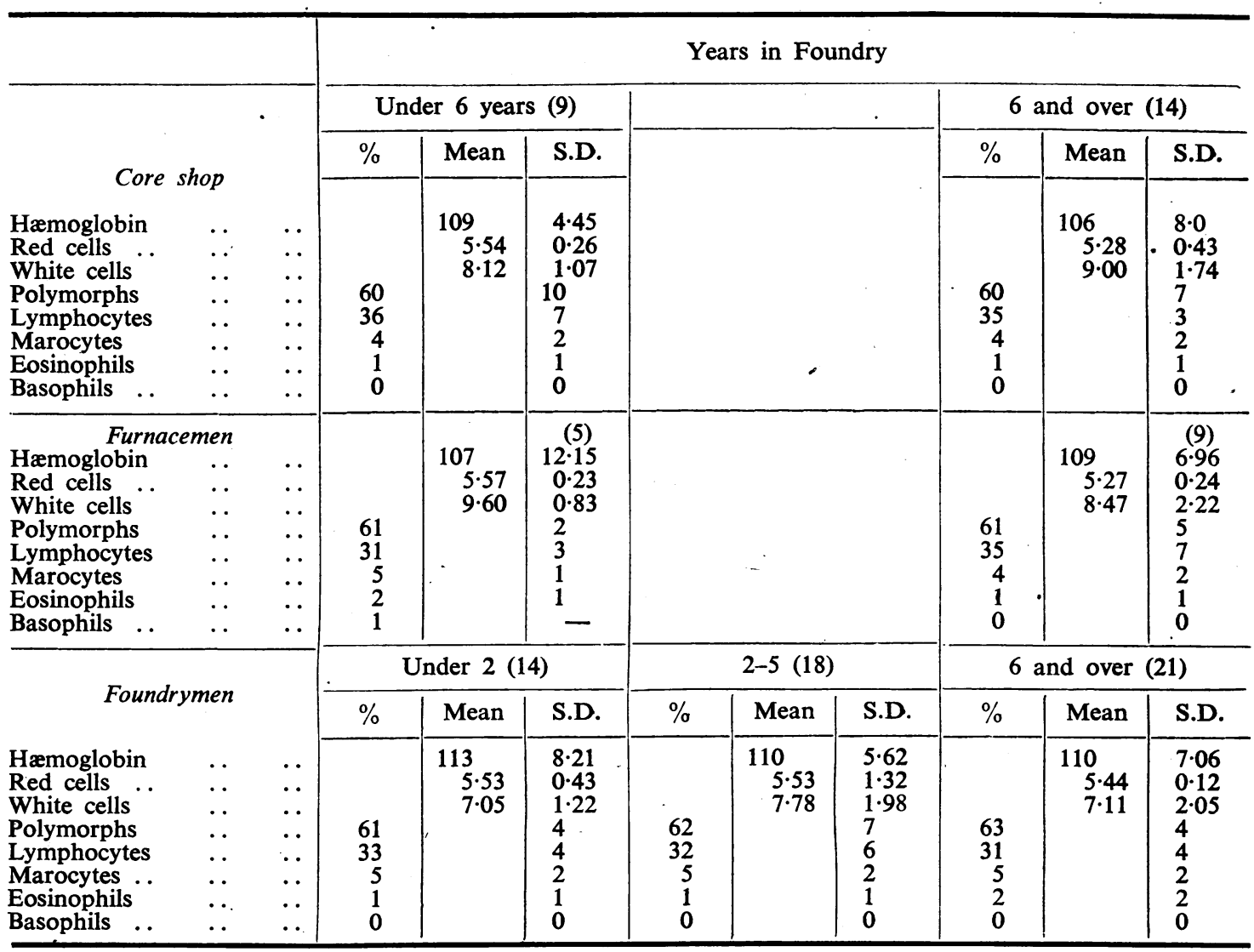


FAble 13

FLUORINE IN SPOT SAMPLES OF URINE IN P.P.M. GROUPED ACCORDING TO LENGTH AND DEGREE OF EXPOSURE

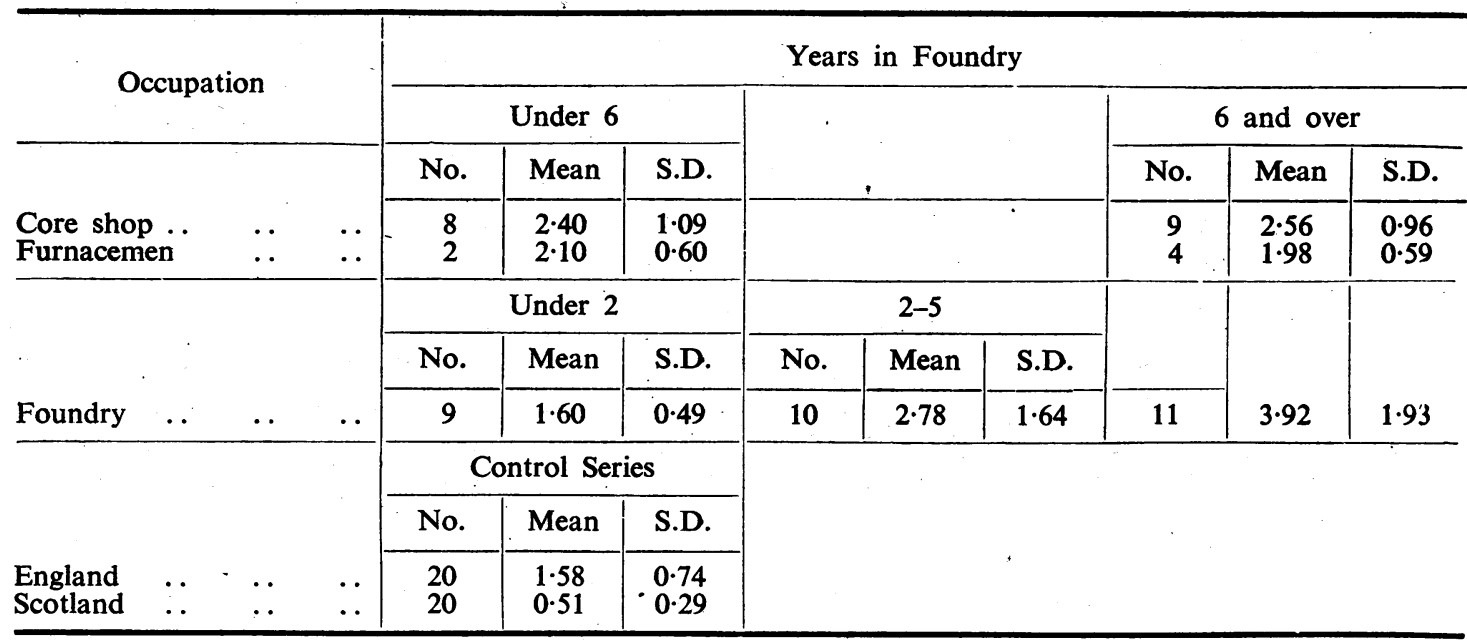

was 112 per cent. His blood contained 4.6 p.p.m. fluorine. The urine was not examined. The radiographs showed a uniform increase of density of the bones, ossification of the ligamentous attachments, and increased density of the tips of the spinal processes (figs. 1 and 2, p. 231).

\section{Conclusion}

It may be suggested, in view of the average raised level of fluorine excretion in the urine of the workers and the fact that one man showed radiological evidence of bone changes, that at least some of the workers in the atmosphere of this magnesium foundry were exposed to a risk of fluorosis.

Roholm (1936) established 15 to $25 \mathrm{mg}$. per day as the probable toxic dose for cryolite. Based on this, Williams (1942) has suggested 3 p.p.m. (2 mg. per cubic metre) as a tentative upper limit for fluorides in magnesium foundries. The concentrations of particulate fluorine in the foundry investigated in Great Britain were only between 0.143 and $0.714 \mathrm{mg}$. per cubic metre, except for a sample taken near the mixing mill, which showed a concentration of $6.37 \mathrm{mg}$. per cubic metre. There is, however, no conclusive evidence that 3 p.p.m. is too high a concentration of atmospheric fluoride for safety, because conditions in this foundry are different in different sections and a man would not be exposed to such a concentration throughout his eight-hour period of work. Nevertheless, the results of this enquiry suggest that improved methods of production should aim at reducing atmospheric contamination by fluorine compounds if such a magnesium foundry is to be entirely free from risk.

\section{Summary}

The results of an investigation into the possible occurrence of fluorosis in workers in a magnesium foundry are described.

Out of 124 persons examined, radiological examination showed only one case suggestive of fluorosis, but only 47 of the workers had been exposed to risk for as long as six years.

There was an increased excretion of fluorine in the urine of the workers in the foundry when compared with two control groups. There was no excess of fluorine in the blood.

The fluorine content of dust collected from the air in the foundry varied between 0.143 and $6.37 \mathrm{mg}$. fluorine per cubic metre. The possible effect of these conditions on the health of the workers is discussed.

We would like to express our gratitude to Dr. A. G. Eddison and the management of High Duty gratitude to Dr. A. G. Eddison We are also indebted to Messrs. H. T. Ferrier and J. Maclagan

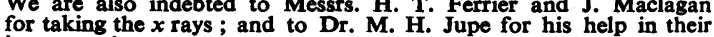
interpretation.

\section{REFERENCES}

Ford, C. B., and Stern, A. C. (1944). Industr. Hyg. Bull., 23, 253. Largent, E.'J.; and Ferneau, I. F. (1944). J. Industr. Hyg. 26, 113. Roholm, K. (1936). Klin. Wschr. 15, 1425.

Willard, H. H., and Winter, O. B. (1933). Ind. Eng. Chem. (Anal. Edit.), $5,7$.

Williams, C. R.'(1942). J. Industr. Hyg. 24̄, 277. 

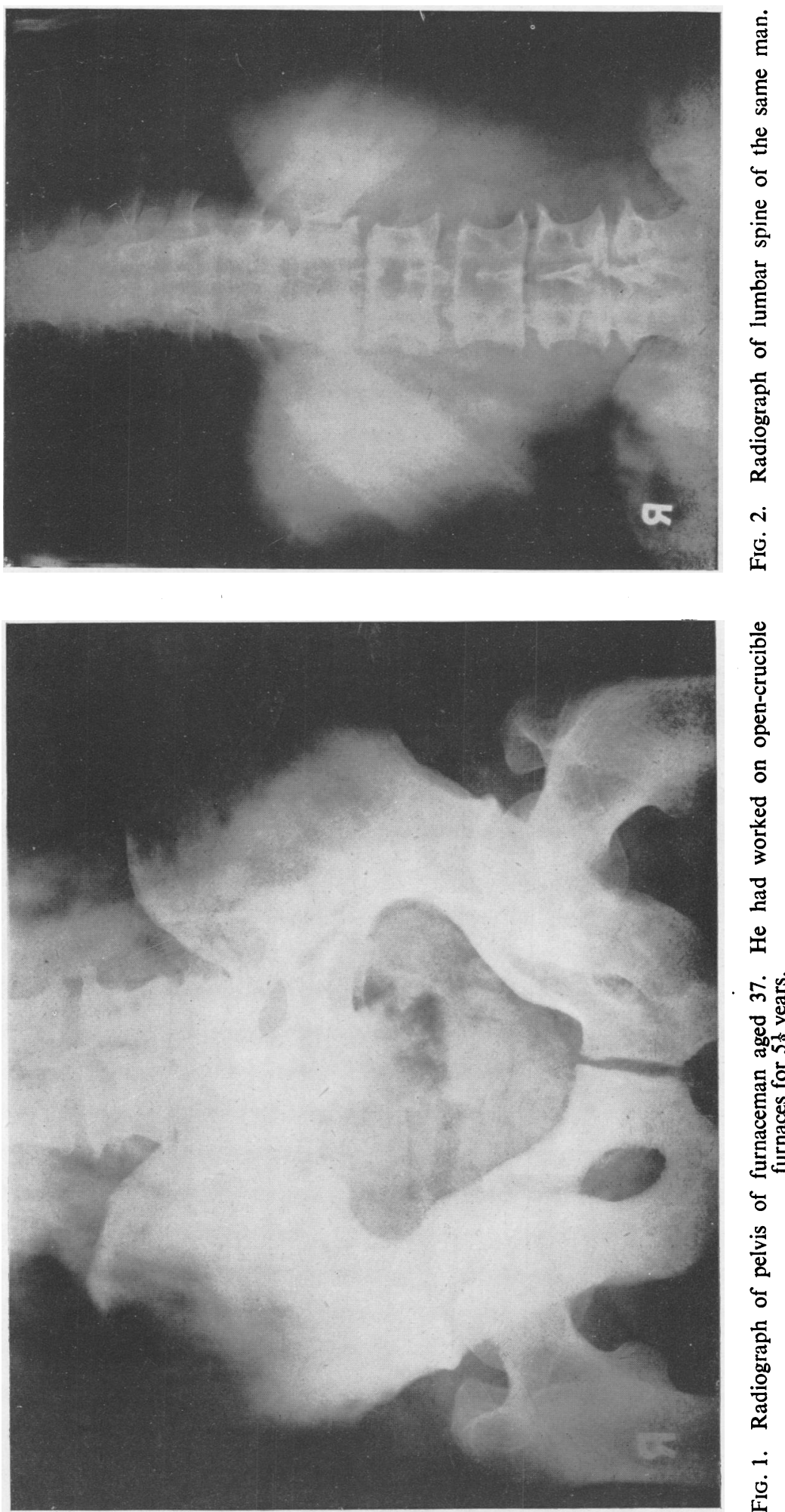